\title{
Wyniki leczenia chorych na nowotwory złośliwe z przerzutami do wątroby: 8-letnie doświadczenie jednego ośrodka
}

\author{
Jerzy Mielko ${ }^{1}$, Andrzej Kurylcio ${ }^{1}$, Marek Sokoluk ${ }^{1}$, Witold Budny ${ }^{1}$, Bogumiła Ciseł², \\ Ewelina Guz ${ }^{3}$, Angelika Gawlik³ ${ }^{3}$ Magdalena Skórzewska², Kinga Franciszkiewicz-Pietrzak', \\ Robert Sitarz ${ }^{1}$, Monika Lewicka², Konrad Krzyżanowski ${ }^{3}$, Witold Krupski ${ }^{3}$, Wojciech P. Polkowski ${ }^{1}$
}

Wstęp. Leczenie chirurgiczne przerzutów nowotworów litych do wątroby powinno odbywać się w ramach zespołu wielodyscyplinarnego.

Cel pracy. Celem pracy jest ocena wyników leczenia skojarzonego chorych na różne nowotwory lite z przerzutami do wątroby przez zespół wielodyscyplinarny jednego ośrodka onkologicznego w ciągu ostatnich 8 lat.

Materiał i metody. Retrospektywną analizą objęto 166 chorych (84 kobiety i 82 mężczyzn) w wieku od 19 do 78 lat (średnia $58 \pm 11,2$ ), leczonych z powodu przerzutów do wątroby pierwotnych nowotworów litych o różnej lokalizacji, z wyjątkiem guzów neuroendokrynnych. Każdorazowo rozważano okołooperacyjne leczenie systemowe zgodnie z aktualnymi zaleceniami Polskiej Unii Onkologii.

Wyniki. W czasie obserwacji (mediana 35 miesięcy) zmarło 46\% chorych. Resekcje wątroby wykonano u 107 (65\%) chorych, w tym u 19 chorych połączono je z (RF-)termoablacją zmian przerzutowych, którą wykonano jako samodzielny zabieg u dalszych 59 (36\%) chorych. Śmiertelność pooperacyjna wyniosła 1,2\%. Powikłania II ${ }^{\circ}$ wg klasyfikacji Clavien-Dindo wystąpiły u 33 (19,8\%) chorych, natomiast III i IV ${ }^{\circ}$ - u 8 (4,8\%) chorych. Przeżycia 1-roczne, 3-letnie i 5-letnie wyniosły odpowiednio 78\%, 41\% i 37\%. Pięcioletnie przeżycia całkowite u chorych na raka jelita grubego po resekcjach przerzutów metachronicznych wyniosły $48 \%$.

Wnioski. Skojarzone leczenie chorych na nieendokrynne nowotwory lite z przerzutami do wątroby przez zespół wielodyscyplinarny jest bezpieczne i skuteczne. W starannie dobranej grupie chorych można osiągnąć blisko 50\% całkowitych przeżyć 5-letnich. Resekcja wątroby jest optymalną metodą leczenia chirurgicznego przerzutów do wątroby.

\section{Results of the treatment of patients with solid tumours and liver metastases:} 8 years experience of one institution

Introduction. Surgical treatment of liver metastases from solid tumours should be provided by multidisciplinary teams. Aim. The aim of the present study is to analyse results of the combined treatment of patients with different solid tumours and liver metastases by single institution multidisciplinary team for last 8 years.

Material and methods. This is a retrospective analysis of 166 patients ( 84 females and 82 males), aged from 19 to 78 years (mean $58 \pm 11.2$ ), treated due to liver metastases from solid tumours in various primary localizations: except neuroendocrine tumours. In every patient, perioperative systemic therapy was evaluated in agreement with current recommendations of the Polish Union of Oncology.

Results. In the follow-up time available (median 35 months) $46 \%$ of patients died. Liver resections were performed in 107 (65\%) patients, including 19 patients in whom resections were supplemented with (RF-)thermoablations of their liver metastases. This was the sole surgical treatment in the 59 (36\%) patients. Perioperative mortality was $1.2 \%$. Grade Il complications according to the Clavien-Dindo classification were found in 33 (19.8\%) patients, whereas grade

\footnotetext{
${ }^{1}$ Klinika Chirurgii Onkologicznej

${ }^{2}$ Oddział Chemioterapii

${ }^{3}$ Studenckie Koło Naukowe przy Klinice Chirurgii Onkologicznej

${ }^{4}$ II Zakład Radiologii Lekarskiej

Uniwersytet Medyczny w Lublinie
} 
III and IV complications were treated in 8 (4.8\%) patients. One-, 3-, and 5-year survival rates were respectively 78\%, $41 \%$, and $37 \%$. Five-year overall survival in patients with colorectal carcinoma after liver resection of metachronous metastases was $48 \%$.

We conclude that combined treatment of patients with liver metastases from non-endocrine solid tumours by the multidisciplinary team is safe and effective. A nearly 50\% 5-year survival is achievable in a carefully selected group of patients. We also conclude that hepatic resection is an optimal method of surgical treatment of liver metastases.

NOWOTWORY Journal of Oncology 2014; 64, 2: 129-134

Słowa kluczowe: przerzuty do wątroby, uogólniony rak jelita grubego, resekcja wątroby, termoablacja guzów wątroby, okołooperacyjne leczenie systemowe, zespół wielodyscyplinarny

Key words: liver metastases, disseminated colorectal carcinoma, hepatic resection, (thermo-) ablation of liver tumours, perioperative systemic treatment, multidisciplinary team

\section{Wstęp}

Przerzuty nowotworów złośliwych do wątroby powstają drogą krwionośną. Najczęściej ognisko pierwotne zlokalizowanie jest w układzie pokarmowym (rak jelita grubego, żołądka, trzustki, dróg żółciowych), a komórki nowotworowe przedostają się do wątroby drogą krwi wrotnej. Obecność przerzutów jedynie do wątroby (M1a) decyduje o zaklasyfikowaniu chorych na raka jelita grubego do czwartego stopnia zaawansowania wg klasyfikacji TNM (7 wydanie z 2010 roku) i świadczy o poważnym rokowaniu. U około $30 \%$ chorych przerzuty do wątroby stwierdza się jednocześnie z rozpoznaniem ogniska pierwotnego (synchroniczne), a u około 45-50\% chorych przerzuty ujawnią się później (metachroniczne). Jedyną szansą na wyleczenie jest mikroskopowo radykalna resekcja (R0) zarówno ogniska pierwotnego, jak i zmian przerzutowych, jednak pierwotne leczenie operacyjne możliwe jest tylko u 10-25\% chorych. U części chorych z przerzutami pierwotnie nieresekcyjnymi możliwe jest osiągnięcie resekcyjności po zastosowaniu chemioterapii indukcyjnej. Wiele kontrowersji budzi przedoperacyjne stosowanie chemioterapii u chorych z przerzutami pierwotnie resekcyjnymi (neoadiuwantowe).W zależności od nowotworu pierwotnego odsetek przeżyć 5-letnich po resekcji R0 przerzutów do wątroby wynosi 25-40\%. Rokowanie oraz korzyści z resekcji wątroby można ocenić w okresie przedoperacyjnym w oparciu o kliniczną ocenę ryzyka. Najczęściej stosowaną punktacjąjest wskaźnik Fonga. Obejmuje on w szczególności liczbę i wielkość przerzutów do wątroby, okresy wolne od choroby oraz poziom CEA [1]. Postęp w dziedzinie obrazowania wątroby, chemio- i immunoterapii, technik ablacyjnych, doskonalenie techniki chirurgicznej i intensywnej opieki okołooperacyjnej może przyczynić się do wzrostu liczby chorych leczonych z intencją wyleczenia [2].

Celem pracy jest ocena wyników leczenia skojarzonego chorych na różne nowotwory lite z przerzutami do wątroby przez zespół wielodyscyplinarny Kliniki Chirurgii Onkologicznej Uniwersytetu Medycznego w Lublinie w ciągu ostatnich 8 lat.

\section{Materiał i metody}

Retrospektywną analizą objęto 166 chorych (84 kobiety i 82 mężczyzn) operowanych od 1 kwietnia 2004 r. do 30 września 2012 r. z powodu przerzutów do wątroby nowotworów litych o różnej lokalizacji, z wyjątkiem guzów neuroendokrynnych. Decyzje lecznicze podejmowane były po omówieniu każdego przypadku przez zespół wielodyscyplinarny, w którego skład wchodzili: radiolog, onkolog kliniczny i chirurg onkologiczny. Wiek chorych wahał się od 19 do 78 lat, średnia 58 (SD $\pm 11,2$ ). U 8 chorych wykonano resekcję przerzutów synchronicznych podczas usunięcia ogniska pierwotnego. Przerzuty, które ujawniły się po 6 miesiącach od momentu wykrycia ogniska pierwotnego, opisywano jako przerzuty metachroniczne. Kwalifikacja do resekcji wątroby odbywała się zawsze na podstawie dwóch badań obrazowych, najczęściej wielofazowej tomografii komputerowej (TK) w połączeniu z ultrasonografią z kontrastem (CEUS) lub rzadziej z rezonansem magnetycznym (MRI) jamy brzusznej. Leczenie systemowe stosowano zgodnie z aktualnymi zaleceniami Polskiej Unii Onkologii [3]. W przypadku pierwotnie nieresekcyjnych lub granicznie resekcyjnych przerzutów do wątroby stosowano chemioterapię indukcyjną/neoadiuwantową według typowych schematów: FOLFIRI, FOLFOX, XELOX u chorych na raka jelita grubego, wyjątkowo rzadko w połączeniu z lekami biologicznie czynnymi (bewacyzumab, cetuksymab). Z powodu ryzyka uszkodzenia wątroby i powikłań pooperacyjnych ponownej oceny resekcyjności dokonywano po zastosowaniu nie więcej niż 5 cykli chemioterapii przedoperacyjnej. Do operacji kwalifikowano chorych po uzyskaniu stabilizacji lub częściowej odpowiedzi wg kryteriów RECIST, także chorych z progresją choroby, leczonych wcześniej systemowo w innych ośrodkach onkologicznych, jeśli na podstawie badań obrazowych stwierdzono jeszcze możliwość przeprowadzenia operacji resekcyjnej lub zniszczenia zmian przerzutowych za pomocą termoablacji.

Resekcje wątroby wykonywano z cięcia poprzecznego typu ",chevron" pod łukami żebrowymi, a dostęp operacyjny 
uzyskiwano z pomocą haka typu Rochard lub Münster. Po uwolnieniu wątroby z więzadeł trójkątnego i sierpowatego wykonywano ultrasonografię śródoperacyjną przy użyciu aparatu USG (Pro Fokus 2202 Ultrasound Scanner) w celu ostatecznej kwalifikacji do zabiegu resekcyjnego i/lub termoablacji. Wyniki ultrasonografii śródoperacyjnej decydowały o ostatecznym zakresie resekcji miąższu wątroby, ustalonym na podstawie przedoperacyjnych badań obrazowych. Do przecinania miąższu wątroby stosowano technikę kellyklazji, aspirator ultradźwiękowy (Cavitron Ultrasonic Surgical Aspirator) lub technikę termoresekcji.W przypadkach dużych resekcji nieanatomicznych wątroby stosowano przerywany manewr Pringle’a, nie dłużej niż 25 minut. Dla uzyskania hemostazy przeciętego miąższu wątroby stosowano beamer argonowy (EMED ES 350) i TachoSil. Operacje resekcyjne uzupełniano rutynowo wykonaniem limfadenektomii więzadła wątrobowo-dwunastniczego, od wnęki wątroby — wzdłuż tętnicy wątrobowej - do odejścia pnia trzewnego.

W przypadkach, w których wycięcie wszystkich zmian przerzutowych nie było możliwe, wykonywano termoablację pojedynczych przerzutów pozostałych po zasadniczej resekcji wątroby. Zabiegi ablacji guzów wątroby wykonywano, wykorzystując wysoką temperaturę $\left(62 \pm 15^{\circ} \mathrm{C}\right)$ wywołaną przepływem prądu o częstotliwości radiowej (radiofrequency ablation), Cool-tip FRA Ablation System), śródoperacyjnie pod kontrolą ultrasonografii śródoperacyjnej (również laparoskopowo), przezskórnie pod kontrolą USG lub TK. Do oceny stopnia powikłań pooperacyjnych zastosowano 5-stopniową klasyfikację Clavien-Dindo ( $\left.{ }^{\circ}-V^{\circ}\right)$ [4].Śmiertelność pooperacyjną określono w czasie hospitalizacji pooperacyjnej (śmiertelność szpitalna).

Badania kontrolne przeprowadzano w Przyklinicznej Poradni Onkologicznej co 3-6 miesięcy. Czas obserwacji wahał się od 1 do 100 (mediana 35) miesięcy. Do analizy przeżycia całkowitego brano pod uwagę datę zgonu chorego z powodu nowotworu złośliwego lub datę ostatniej obserwacji chorego. Z obserwacji utracono 8 (5\%) chorych. Analizę statystyczną przeprowadzono, stosując metodę Kaplana-Meiera do obliczenia skumulowanej proporcji przeżywających oraz test log-rank do porównywania krzywych przeżycia (określania istotności różnic). Przyjęto poziom istotności statystycznej $p<0,05$. Do obliczeń statystycznych wykorzystano pakiet STATISTICA 10.

\section{Wyniki}

Tabela I przedstawia dane demograficzne i cechy kliniczne 166 leczonych chorych. W czasie obserwacji zmarło $76(46 \%)$ chorych. Synchroniczne przerzuty stwierdzono u 65 (39\%) chorych, natomiast w pozostałych 101 (61\%) przypadkach były to przerzuty metachroniczne, których czas od leczenia ogniska pierwotnego do rozpoznania wahał się od 6 do 72 (mediana 28) miesięcy. U 131 (79\%) chorych operowanych pierwotne ognisko było zlokalizowane
Tabela I. Dane demograficzne i cechy kliniczne

\begin{tabular}{|c|c|}
\hline \multicolumn{2}{|c|}{ Dane demograficzne i cechy kliniczne } \\
\hline Liczba chorych & 166 \\
\hline Wiek (zakres, mediana \pm SD) & 19 do 78 , mediana $58 \mathrm{SD} \pm 11,2$ \\
\hline \multicolumn{2}{|l|}{ Przerzuty } \\
\hline synchroniczne & $68(41 \%)$ \\
\hline metachroniczne & $98(59 \%)$ \\
\hline \multicolumn{2}{|l|}{$\begin{array}{l}\text { Lokalizacja ogniska } \\
\text { pierwotnego }\end{array}$} \\
\hline jelito grube & $131(79 \%)$ \\
\hline okrężnica & 67 \\
\hline odbytnica & 49 \\
\hline inne & $35(21 \%)$ \\
\hline pierś & 14 \\
\hline trzustka & 5 \\
\hline pęcherzyk żółciowy & 4 \\
\hline nerka & 2 \\
\hline płuco & 2 \\
\hline żołądek & 2 \\
\hline wątroba & 2 \\
\hline macica & 2 \\
\hline teratoma & 1 \\
\hline ślinianka & 1 \\
\hline $\begin{array}{l}\text { Liczba przerzutów (zakres, } \\
\text { mediana, średnia } \pm S D \text { ) }\end{array}$ & $1-7,2,2,1 \mathrm{SD} \pm 1,3$ \\
\hline
\end{tabular}

w jelicie grubym [okrężnica 67 (51\%), odbytnica 64 (49\%)]. Czternaście chorych operowano z powodu przerzutów do wątroby w przebiegu raka piersi, 5 w przebiegu raka trzustki, 4 w przebiegu raka pęcherzyka żółciowego. Liczba przerzutów stwierdzonych podczas operacji wahała się od 1 do 7 , średnio 2,1; mediana 2 (SD $\pm 1,3$ ).

Tabela II przedstawia wyniki postępowania chirurgicznego. Zabieg resekcyjny wykonano u 107 (65\%) chorych. Hemihepatektomię (wycięcie co najmniej 3 segmentów) wykonano u 20 chorych, w tym rozszerzoną prawostronną u 4 chorych, prawostronną u 10 chorych, lewostronną u 6 chorych. Anatomiczne resekcje segmentarne wykonano u 49 chorych. Resekcje nieanatomiczne wątroby (metastazekotmię) wykonano u 19 chorych. U 19 (11\%) chorych połączono zabiegi resekcyjne i ablację zmian przerzutowych. U 59 (36\%) chorych wykonano zabiegi termoablacji guza. U 3 chorych zabieg ablacji wykonano w sedacji w znieczuleniu miejscowym, przezskórnie, pod kontrolą USG lub TK, u 3 chorych wykonano ablację podczas laparoskopii pod kontrola śródoperacyjnej ultrasonografii. U 53 chorych zabieg wykonano metodą otwartą pod kontrolą śródoperacyjnej ultrasonografii. Czas trwania zabiegu wahał się od 30 do 320 min, średnio 130 min (SD \pm 54 ). Średni czas trwania zabiegu w przypadku resekcji wynosił 143 min, a w przypadku termoablacji $-124 \min (p=0,2$; test $t$-Studenta). 
Tabela II. Postępowanie chirurgiczne

\begin{tabular}{|c|c|}
\hline Resekcja & $88(53 \%)$ \\
\hline segmentektomia & 16 \\
\hline bisegmentektomia & 33 \\
\hline hemihepatektomia & 20 \\
\hline metastazektomia (nieanatomiczna) & 19 \\
\hline Ablacja & $59(36 \%)$ \\
\hline \multicolumn{2}{|l|}{ dostęp } \\
\hline laparotomia & 53 \\
\hline laparoskopia & 3 \\
\hline przezskórna & 3 \\
\hline \multicolumn{2}{|l|}{ liczba } \\
\hline pojedyncza & 28 \\
\hline wielokrotna & 31 \\
\hline Resekcja i ablacja & $19(11 \%)$ \\
\hline Jednoczasowa resekcja ogniska pierwotnego & 8 \\
\hline $\begin{array}{l}\text { Czas trwania zabiegu min (zakres, } \\
\text { średnia } \pm \text { SD) }\end{array}$ & $\begin{array}{c}30-320 \\
130 \mathrm{SD} \pm 54\end{array}$ \\
\hline Śródoperacyjne badanie USG & $145(87 \%)$ \\
\hline $\begin{array}{l}\text { Czas hospitalizacji pooperacyjnej (zakres, } \\
\text { średnia } \pm \text { SD) }\end{array}$ & $4-22,7, S D \pm 3,2$ \\
\hline Transfuzja KKCz & $33(19,8 \%)$ \\
\hline
\end{tabular}

W okresie pooperacyjnym stwierdzono dwa zgony w 3. i 16. dobie po operacji (Vo). Przyczyną zgonu u jednego chorego była niewydolność krążenia w przebiegu ostrego niedokrwienia mięśnia sercowego, natomiast u drugiego chorego - niewydolność oddechowa i wielonarządowa w przebiegu stanu septycznego. Śmiertelność pooperacyjna wyniosła 1,2\%.

Trzydziestu trzech chorych $(19,8 \%)$ po zabiegach resekcyjnych wymagało przetoczenia koncentratu krwinek czerwonych w przebiegu pooperacyjnym $\left(\mathrm{II}^{\circ}\right), 6$ chorych wymagało ponownej interwencji chirurgicznej (relaparotomii) w przebiegu pooperacyjnym (z powodu krwawienia u 3 chorych; zapalenia pęcherzyka żółciowego u 1 chorego, zapalenie otrzewnej w wyniku perforacji wrzodu żołądka u 1 chorego, nasilonego przecieku żółciowego u 1 chorego (III); dwóch chorych wymagało leczenia na oddziale intensywnej terapii z powodu pooperacyjnej niewydolności krążeniowo-oddechowej, niewydolności wielonarządowej $\left(\mathrm{IV}^{\circ}\right)$.

Przeżycia 1-roczne, 3-letnie i 5-letnie w badanej grupie chorych wyniosły odpowiednio $81 \%, 49 \%$ i $37 \%$ (ryc. 1). Przeżycia 5-letnie w zależności od lokalizacji ogniska pierwotnego przedstawia rycina 2. Przeżycia w poszczególnych grupach przedstawiono w tabeli III. Pięcioletnie przeżycia całkowite u chorych na raka jelita grubego po resekcjach przerzutów metachronicznych wyniosły $48 \%$.

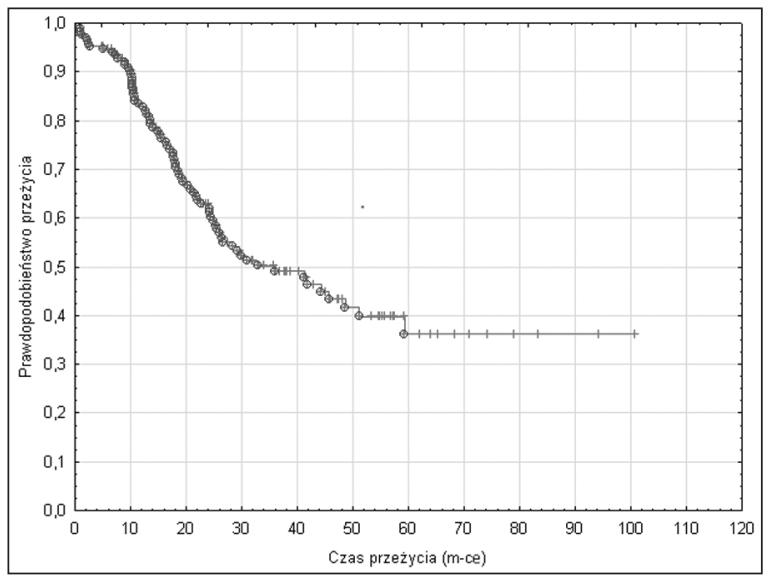

Rycina 1. Krzywa Kaplana-Meiera przedstawiająca prawdopodobieństwo przeżycia całkowitego w całej grupie chorych

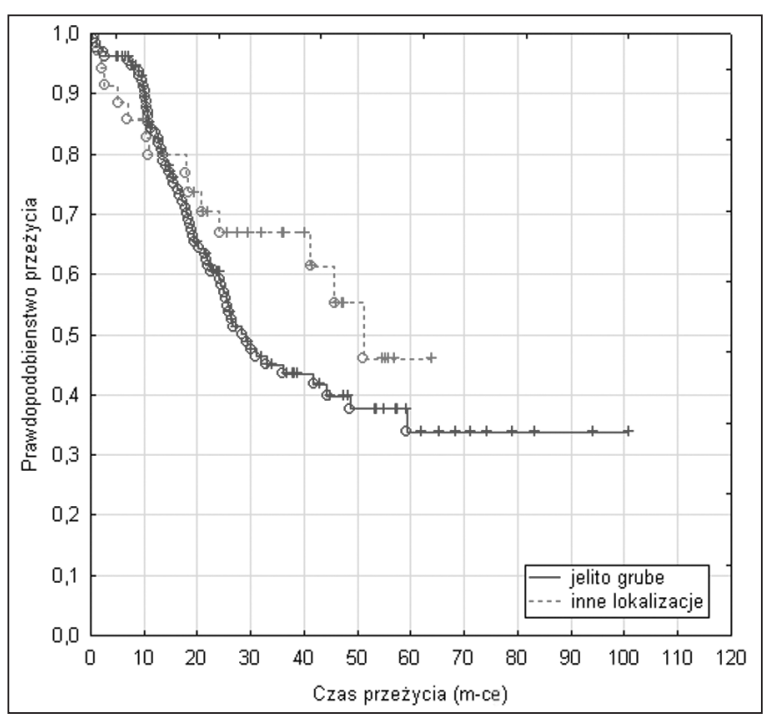

Rycina 2. Krzywe Kaplana-Meiera przedstawiające prawdopodobieństwo przeżycia chorych w zależności od lokalizacji ogniska pierwotnego (jelito grube vs. inne lokalizacje), $p=0,2$ test log-rank

\section{Dyskusja}

W ciągu ostatnich lat radykalne leczenie chirurgiczne chorych z przerzutami do wątroby doprowadziło do znamiennej poprawy rokowania, co odzwierciedla odsetek przeżyć 5-letnich często przekraczający 40\%, przy niskiej śmiertelności i zachorowalności okołooperacyjnej. Europejska baza danych (LiverMetSurvey) w chwili obecnej gromadzi wyniki leczenia około 20000 chorych leczonych z powodu przerzutów do wątroby w przebiegu raka jelita grubego (http://www.livermetsurvey.org/). Odsetek przeżyć 5-letnich w bazie LiverMetSurvey wynosi $42 \%$. W podobnej grupie chorych leczonych w naszym ośrodku, przeżycia 5-letnie wynoszą 44\%. Według innych autorów przeżycia 5-letnie w grupie chorych leczonych z powodu przerzutów raka 
Tabela III. Przeżycia w poszczególnych grupach chorych

\begin{tabular}{|c|c|c|c|c|}
\hline & 1-roczne & 3-letnie & 5-letnie & $\mathrm{p}$ (test log-rank) \\
\hline Przeżycia całkowite & $80 \%$ & $44 \%$ & $33 \%$ & \\
\hline \multicolumn{5}{|l|}{ Typ zabiegu } \\
\hline resekcja & $75 \%$ & $50 \%$ & $41 \%$ & 0,5 \\
\hline ablacja & $88 \%$ & $48 \%$ & $28 \%$ & \\
\hline \multicolumn{5}{|c|}{ Lokalizacja ogniska pierwotnego } \\
\hline jelito grube & $82 \%$ & $43 \%$ & $44 \%$ & 0,2 \\
\hline inne & $80 \%$ & $66 \%$ & $53 \%$ & \\
\hline \multicolumn{5}{|l|}{ Liczba przerzutów } \\
\hline$<3$ & $81 \%$ & $51 \%$ & $33 \%$ & 0,7 \\
\hline$\geq 3$ & $88 \%$ & $41 \%$ & $41 \%$ & \\
\hline \multicolumn{5}{|c|}{ W zależności od czasu powstania } \\
\hline synchroniczne & $80 \%$ & $43 \%$ & $26 \%$ & 0,2 \\
\hline metachroniczne & $82 \%$ & $53 \%$ & $48 \%$ & \\
\hline
\end{tabular}

jelita grubego wahają się od 38 do 59\% . Łączenie zabiegów resekcyjnych z ablacją zmian przerzutowych jest bezpieczną i skuteczną metodą, pozwalającą osiągnąć długoterminowe przeżycia (w naszej grupie odsetek przeżyć 5-letnich wynosił 37\%). Zastosowanie termoablacji podczas resekcji może być korzystne u chorych z rozpoznanymi nieoperacyjnymi przerzutami do wątroby [5].

Leczenie chirurgiczne przerzutów do wątroby jest bezpieczne w wyspecjalizowanych ośrodkach. Wyniki wczesne (śmiertelność pooperacyjna, odsetek powikłań) uzyskane w naszej Klinice są porównywalne do tych, jakie uzyskuje się w wyspecjalizowanych ośrodkach chirurgii wątroby (powikłania - 28\%; śmiertelność 90-dniowa - 4,7\%) [6].

Podejmowanie decyzji przez zespół wielodyscyplinarny pozwala znacznie zwiększyć odsetek chorych leczonych z powodu wtórnych nowotworów wątroby. Jones i wsp. dokonali analizy 110 chorych zakwalifikowanych przez onkologów klinicznych (bez udziału chirurgów onkologicznych wyspecjalizowanych w chirurgii wątroby) do chemioterapii paliatywnej z powodu przerzutów raka jelita grubego do wątroby. Choroba była ograniczona do wątroby u 53 chorych, wśród których zmiany resekcyjne stwierdzono u 33 chorych [7]. Międzynarodowy zespół ekspertów opracował zagadnienia dotyczące leczenia chorych z przerzutami raka jelita grubego do wątroby [8]. Celem była standaryzacja leczenia chorych w różnych ośrodkach. Zostały przyjęte następujące uzgodnienia: a) podstawowym celem leczenia jest osiągnięcie długiego czasu przeżycia wolnego od choroby; b) ocena resekcyjności powinna być wykonywana na podstawie jakościowo dobrych badań obrazowych (MRI i /lub tomografii komputerowej, badanie FDG-PET u chorych z dużym ryzykiem przerzutów pozawątrobowych), zastosowanie ultrasonografii śródodoperacyjnej (najlepiej z kontrastem); c) zastosowanie optymalnej chemioterapii pierwszego rzutu w połączeniu z terapią celowaną u chorych potencjalnie resekcyjnych; d) podanie co najmniej czterech kursów chemioterapii pierwszego rzutu z oceną odpowiedzi co 2 miesiące; e) ocena odpowiedzi na podstawie kryteriów RECIST (Response Evaluation Criteria in Solid Tumors) w przypadku konwencjonalnej chemioterapii lub ocena innych parametrów jakościowych w przypadku połączenia chemioterapii z przeciwciałami;f) czas trwania chemioterapii powinien być tak krótki, jak jest to możliwe, a resekcja powinna być wykonana najszybciej, jak będzie możliwa; g) liczba przerzutów i/lub wiek pacjenta nie powinny stanowić przeciwwskazania do zabiegu i chemioterapii; h) w przypadku przerzutów synchronicznych nie jest wskazane wykonanie dużej operacji wątroby podczas leczenia operacyjnego ogniska pierwotnego. Wykonanie zabiegu w odwrotnej kolejności (najpierw wątroba) pozwala uzyskać równie dobre wyniki; i) zastosowanie okołooperacyjnej chemioterapii pozwala wydłużyć czas przeżycia wolny od choroby; j) całkowita resekcja przerzutów pozwala wyleczyć lub uzyskać długi czas przeżycia, podejmowanie decyzji leczniczej w zespole wielodyscyplinarnym znacznie poprawia efekty leczenia przerzutów raka jelita grubego do wątroby.

W ciągu ostatnich dwudziestu lat wzrasta liczba chorych leczonych operacyjnie z powodu przerzutów do wątroby nowotworów pierwotnych innych niż rak jelita grubego. Resekcja wątroby z powodu przerzutów u chorych na inne nowotwory jest zasadna, szczególnie w wybranych sytuacjach (typ gruczołowy raka, rozsiew ograniczony do wątroby, długi okres wolny od nawrotu) oraz gdy leczenie chirurgiczne połączone jest z uzupełniającym leczeniem systemowym.. Grupa lokalizacji nowotworowych o najlepszym rokowaniu (> 30\% przeżyć 5-letnich) obejmuje: nadnercza, jądra, jajniki, jelito cienkie, brodawkę Vatera, pierś, nerki i macicę [9]. Nieresekcyjne przerzuty do wątroby u chorych na nowotwory neuroendokrynne są wskazaniem do transplantacji wątroby [10]. 
W naszej grupie chorych leczonych operacyjnie z powodu przerzutów do wątroby nowotworów pierwotnych innych niż rak jelita grubego odsetek przeżyć pięcioletnich wynosił 53\%. Większość tych chorych była operowana z powodu pojedynczych zmian w wątrobie. Wykonano u nich zabieg resekcyjny.

\section{Wnioski}

Skojarzone leczenie chorych na nieendokrynne nowotwory lite z przerzutami do wątroby przez zespół wielodyscyplinarny jest bezpieczne i skuteczne. W starannie dobranej grupie chorych można osiągnąć blisko 50\% całkowitych przeżyć 5-letnich. Resekcja wątroby jest optymalną metodą leczenia chirurgicznego przerzutów do wątroby.

\section{Konflikt interesu: nie zgłoszono}

\section{Prof. dr hab. n. med. Wojciech P. Polkowski}

Klinika Chirurgii Onkologicznej Uniwersytetu Medycznego

w Lublinie, SPSK 1

ul. Staszica 11, 20-081 Lublin

e-mail:wojciech.polkowski@umlub.pl

Otrzymano: 10 lipca 2013 r.

Przyjęto do druku: 12 września 2013 r.

\section{Piśmiennictwo}

1. Fong Y, Fortner J, Sun RL i wsp. Clinical score for predicting recurrence after hepatic resection for metastatic colorectal cancer: analysis of 1001 consecutive cases. Ann Surg 1999; 230: 309-318.

2. Jones RP, Malik HZ, Fenwick SW i wsp. Perioperative chemotherapy for resectable colorectal liver metastases: Where now? Eur J Surg Oncol 2013; 39: 807-811.

3. Potemski P, Polkowski W, Bujko K i wsp. Zalecenia postępowania diagnostyczno-terapeutycznego w nowotworach złośliwych. Nowotwory układu pokarmowego Potemski P, Polkowski W (red.). Tom 1. Gdańsk: Via Medica; 2013, 172-178.

4. Clavien PA, Barkun J, de Oliveira MLi wsp. The Clavien-Dindo classification of surgical complications: five-year experience. Ann Surg 2009; 250: 187-196.

5. Stattner S, Jones RP, Yip VS i wsp. Microwave ablation with or without resection for colorectal liver metastases. Eur JSurg Oncol 2013; 39:844-849.

6. Grat $\mathrm{M}$, Hołówko W, Lewandowski Z i wsp. Early post-operative prediction of morbidity and mortality after a major liver resection for colorectal metastases. HPB (Oxford) 2013; 15: 352-358.

7. Jones RP, Vauthey JN, Adam R i wsp. Effect of specialist decision-making on treatment strategies for colorectal liver metastases. Br J Surg 2012; 99: $1263-1269$.

8. Adam R, De Gramont A, Figueras J i wsp. The oncosurgery approach to managing liver metastases from colorectal cancer: a multidisciplinary international consensus. Oncologist 2012; 17: 1225-1239.

9. Adam R, Chiche L, Aloia T i wsp. Hepatic resection for noncolorectal nonendocrine liver metastases: analysis of 1,452 patients and development of a prognostic model. Ann Surg 2006; 244: 524-535.

10. Le Treut YP, Gregoire E, Klempnauer J i wsp. Liver transplantation for neuroendocrine tumors in Europe-results and trends in patient selection: a 213-case European liver transplant registry study. Ann Surg 2013; 257: 807-815.

W dniach 27-28 czerwca 2014 r. odbędzie się w Gdańsku trzynaste „Spotkanie Po ASCO”

\author{
Organizatorzy: \\ Oddział Gdański Polskiego Towarzystwa Onkologicznego \\ Stowarzyszenie "Gdańskiej Onkologii" \\ Polskie Towarzystwo Onkologii Klinicznej
}

Celem konferencji jest przedstawienie najciekawszych doniesień z konferencji ASCO 2014, które odbędzie się w Chicago w dniach 30 maja-3 czerwca 2014 r.

Miejsce:

Polska Filharmonia Bałtycka w Gdańsku

Liczba uczestników jest ograniczona, o kwalifikacji decyduje kolejność zgłoszeń.

W ramach opłaty zjazdowej zapewniamy materiały zjazdowe, posiłki oraz udział w spotkaniu towarzyskim.

Zgłoszenia można dokonać wyłącznie poprzez stronę internetową www.poasco.pl.

Informacje:

ul. Sobieskiego 64/2, 80-216 Gdańsk

tel.: 5834047 25, faks: 583404727

e-mail: biuro@poasco.pl 